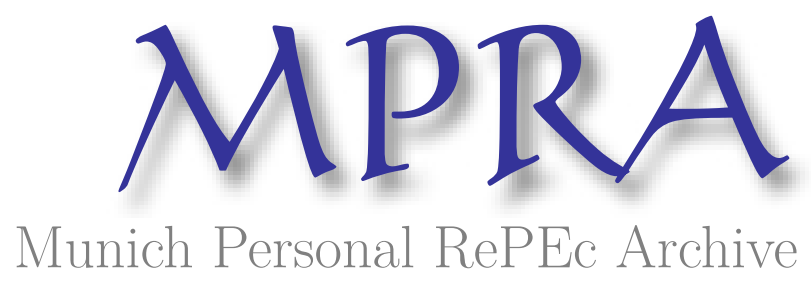

\title{
Optimal financial inclusion
}

Ozili, Peterson K

2020

Online at https://mpra.ub.uni-muenchen.de/101808/

MPRA Paper No. 101808, posted 15 Jul 2020 09:34 UTC 


\title{
Optimal financial inclusion
}

\author{
Peterson K. Ozili
}

\begin{abstract}
This article reports the conditions for optimality in financial inclusion. The optimal level of financial inclusion is achieved when basic financial services are provided to members of the population at a price that is affordable and that price is also economically sufficient to encourage providers of financial services to provide such financial services on a continual basis. Any level of financial inclusion that does not meet these conditions is sub-optimal. The consequence of sub-optimal levels of financial inclusion are reported and I show that maintaining a sub-optimal level of financial inclusion - which is common in many countries - is incentive-inefficient both for users and suppliers of basic financial services.
\end{abstract}

Keywords: financial inclusion, optimal financial inclusion, excluded population, demand-side financial inclusion, supply-side financial inclusion. 


\section{Introduction}

This article reports the conditions for optimality in achieving the goals of financial inclusion. Financial inclusion is the process of granting access to basic financial services to everyone, particularly households and poor individuals. Achieving full financial inclusion or a reasonable level of financial inclusion has been a major policy objective for financial regulators - and ultimately governments - across the world in recent years. Several studies in the literature argue that financial inclusion can reduce poverty levels and improve people's welfare (see Jones, 2008; Cnaan et al, 2012; Hannig and Jansen, 2010, Ozili, 2018). Empirical studies also document evidence which show that greater financial inclusion can reduce poverty levels and improve the economic wellbeing of households and poor individuals (see Chibba, 2009; Neaime and Gaysset, 2018). Policy makers also see some merits in financial inclusion - they believe that high levels of financial inclusion are desirable and good for society because it opens up several economic opportunities for households and poor individuals to engage in entrepreneurial activities, investment, savings and consumption, which can have positive effects for the economy of a country (Beck et al, 2009; Anzoategui et al, 2011; Mitton, 2008).

Notwithstanding, the enthusiasm towards the financial inclusion movement and the desire of policy makers to increase the level of financial inclusion to high levels have led to warnings particularly those relating to high costs, low marginal benefits and sustainability issues (Bhanot, Bapat and Bera, 2012; Ozili, 2020), which raises three major questions: how high can the level of financial inclusion be to sustain economic growth, to improve welfare and to reduce poverty levels? How much financial inclusion is too much and how much is too little? Is there an equilibrium or optimal level of financial inclusion that is incentive-efficient both for users of financial services and providers of financial services? This paper addresses the third question.

This paper assesses optimality in financial inclusion from the demand-side and supply-side incentives, focusing on the extent to which members of the population can afford basic financial services (demandside), the willingness of providers of financial services to offer basic financial services (supply-side), and the costs and benefits of financial inclusion. In assessing the costs and benefits of financial inclusion as a pre-condition for optimality, it is important to take into account a range of factors or conditions such as: (i) access to basic financial services, (ii) the price at which financial services are being offered to the poorest and excluded population, (iii) the capacity of the poorest and excluded population to pay for basic financial services, (iv) the extent to which changes in the average cost of financial services can influence users' decision to use or withdraw from using basic financial services and (v) whether the price is economically sufficient to encourage the provision of such financial services on a continual basis. Few studies try to take into account some of these factors or conditions (see Ranjani and Bapat, 2015; Agarwal, 2007; Ozili, 2018), but these studies did not consider the optimal level of financial inclusion or the conditions for optimality in financial inclusion.

This article identifies some conditions for optimality in financial inclusion, and argue that the optimal level of financial inclusion is achieved when basic financial services are provided to members of the population, at a price that is affordable, and that price is also economically sufficient to encourage providers of 
financial services to provide such financial services on a continual basis. Any level of financial inclusion that does not meet these conditions is sub-optimal.

The study contributes to the literature in the following way. One, it contributes to the studies that examine the role of financial inclusion for economic development (see., Sarma and Pais, 2011; Allen et al, 2016; Ozili, 2020). Two, the literature has not explored what constitutes the optimal level of financial inclusion. This paper bridges this existing gap by identifying the consequences of 'too much' or 'too little' financial inclusion, and to determine an optimal level of financial inclusion that simultaneously achieves the goal of improve economic wellbeing and poverty reduction.

The rest of the article is structured in the following way. Section 2 presents an overview of financial inclusion. Section 3 presents some critical perspectives on financial inclusion. Section 4 discusses suboptimal financial inclusion, and the implication of under-supply and over-supply of basic financial services is discussed. Section 5 discuss the conditions for optimal financial inclusion. Section 6 concludes.

\section{Financial inclusion - an overview}

\subsection{Early History}

The financial inclusion discourse began after Robert Ayres gave a strong critique against the World Bank in the 1980s. Robert Ayres, in his book titled "Banking on the poor: the World Bank and world poverty", argued that the tactics used to spur economic growth in the 1980s and 1990s including some of the tactics used by the World bank made the rich richer, harmed the poor, and vastly increased inequality (Ayres, 1983). This profound critique led to other significant events such as the IMF/World Bank protests in 1988 where protesters demonstrated against the World Bank/IMF's austerity policies towards developing nations which negatively affected several countries. The World bank, in response to these protests, introduced financial inclusion as a global development agenda in the 2000s to increase the participation of citizens in the formal financial sector of their countries and to improve their economic welfare.

In recent years, the World bank has led the financial inclusion project around the world by issuing profinancial inclusion pronouncements and publications, and supporting government officials in achieving their financial development goals. In the last decade, development economists have become interested in financial inclusion policy debates because they believe that a 'financial inclusion' policy agenda is prodevelopment (see Mohan, 2006; Jones, 2008; Hannig and Jansen, 2010). Academics have recently joined the debate on financial inclusion to determine whether financial inclusion outcomes affect the level of economic development particularly poverty reduction, access to finance and employment levels (for example, Park and Mercado, 2015; Arun and Kamath, 2015; Sarma and Pais, 2011).

\subsection{Defining financial inclusion}

There are several definitions of financial inclusion. For instance, financial inclusion can be viewed as the sustainable provision of affordable financial services that bring the poorest and excluded population into the formal economy (United Nations, 2016). Two, financial inclusion is the use of formal financial services by the poor (Beck et al, 2007; Bruhn and Love, 2014). Three, financial inclusion involves increasing the 
number of individuals, mostly poor adults, that have access to formal financial services mainly through having formal bank accounts, which contributes to poverty reduction and economic growth (Ozili, 2018). Four, financial inclusion is the process that ensures availability and ease of access to the formal financial system for all members in the economy (Sarma, 2012). Five, financial inclusion is the share of individuals and firms that use financial services (Demirgüç-Kunt, 2014). Six, financial inclusion is the process of ensuring access to appropriate financial products and services needed by all sections of the society, especially vulnerable groups and low income groups, at an affordable cost in a fair and transparent manner by regulated mainstream institutional players (Chakrabarty, 2011). Seven, financial inclusion is defined as access for individuals to appropriate financial products and services (Hayton et al, 2007). Eight, financial inclusion refers to all the initiatives that make formal financial services available, accessible and affordable to all segments of the population (Triki and Faye, 2013).

These definitions have a common denominator which is that they emphasize that financial inclusion is achieved when there is access to financial services for all or some members of the population. However, the definitions differ in terms of the group of people that benefits from financial inclusion. As can be seen above, some definitions state that the entire population will (or should) benefit from financial inclusion while others suggest that only some excluded groups will (or should) benefit from financial inclusion such as poor adults, women and poor households.

\subsection{Benefits of financial inclusion}

Financial inclusion through account ownership in a formal financial institution can be used for several purposes, and offers many benefits to individuals, businesses and the economy. Financial inclusion has benefits for individuals. Financial inclusion would introduce a savings culture that allow individuals to manage their cash inflows and outflows. Financial inclusion would also make insurance available to everyone. Insurance can help poor households mitigate risk and manage shocks (Cull et al, 2014). Account ownership by individuals in formal financial institutions will also open up a wide range of opportunities and a variety of financial products which are standardized and offered by financial institutions that are closely regulated and supervised by regulators, and are therefore safer (Mohan, 2006). Financial system regulators also benefit from financial inclusion because transactions through individual bank accounts leaves an audit trail which is available to monitor the flow of funds in the financial system, and financial transactions conducted transparently through formal accounts can be monitored (Mohan, 2006).

Financial institutions also benefit from financial inclusion. Through financial inclusion, a wide variety of funding opportunities are available to businesses. Financial institutions can ensure that greater financial resources are allocated through efficient intermediation. Financial institutions will be able to focus on allocation efficiency to ensure that allocated funds yield the highest returns. (Mohan, 2006). The economy also benefits from financial inclusion. Financial inclusion would make credit available to small businesses which would boost the level of local economic activities. Financial inclusion will also allow financial markets to be within the reach of all citizens that want to engage in economic activities (Cull et al, 2014).

The recent empirical literature provides evidence on the positive benefits of financial inclusion in promoting wellbeing for individuals and households. For instance, Allen et al (2016) show that financial inclusion ensures that access to finance is extended to the disadvantaged groups in society through 
greater use of formal bank account and savings. Ahamed and Mallick (2019) show that financial inclusion is good for bank stability in that greater financial inclusion leads to greater bank stability especially for banks with higher market power and for banks that operate in countries where political stability, rule of law, and regulatory environment are stronger. Beck, Demirgüc-Kunt and Levine (2007) and Bruhn and Love (2014) argue that financial inclusion makes it possible for individuals to invest in education and launch businesses which contributes to poverty reduction and economic growth. Han and Melecky (2013) argue that financial inclusion gives individuals the opportunity of having a safe place to save their money in the bank as deposits, and banks are able to use the deposits to increase their deposit base for stability

in troubled times. Kim, Yu and Hassan (2018), in an empirical study, find that financial inclusion has a positive effect on economic growth in Islamic countries (OIC) countries.

\section{Critical perspectives on financial inclusion}

There are concerns that financial inclusion will spread the risks of the financial system to the poor and vulnerable users of financial services, and can increase the number of high-end and middle-end consumers benefiting from financial institutions at the expense of poor customers (Ozili, 2018; Ozili, 2020). Critics argue that financial inclusion will expose poor and vulnerable customers to financial risks in the financial sector, and these customers are unable to insure themselves against financial losses from fraud and identity theft, coupled with the little protection for vulnerable customers who have little money in their formal accounts whose money are at risk. Ozili (2018) argued that the financial sector should be de-risked before bringing in poor households into the formal financial sector in order to protect poor and vulnerable customers.

Secondly, recent global development trends suggest that microfinance as a driver for development is gradually being phased out as a development agenda and replaced with the 'financial inclusion' agenda. Critics of financial inclusion argue that financial inclusion is a rebranded form of microfinance because much of today's financial inclusion activities are still microfinance activities such as giving small, shortterm, high-interest loans to low-income people (Mader, 2018). Microfinance as a driver for development is being replaced with the 'financial inclusion' agenda because of the major problems of microfinance institutions which are primarily the excessive focus on credit over other financial services (Mader 2018), lack of demonstrable poverty-reducing impact (Duvendack et al. 2011), failure to empower women (Fraser, 2011), and over-indebtedness (Guérin et al. 2015), and these challenges justify why there are concerns that today's financial inclusion agenda is just a rebranded type of microfinance or a type of 'baitand-switch' terminology, which is doomed to fail just like the failed microfinance project.

Another criticism of financial inclusion is that financial inclusion can lead to the financialisation of society which some critics argue is an invitation to everyone to live by finance (Mader, 2018). There are concerns that achieving full financial inclusion may lead to the commodification of people's livelihood and the financialisation of all facets of society (Mader, 2018), and as a result, the social consequences of financialising society might be severe. Financial inclusion can make everyone live by finance which can undermine other areas of life that do not require money or credit for people to live their lives to the fullest. Financialising society can also lead to severe consequences during a financial crisis because a large 
number of people in formal financial sector will be affected especially poor households and individuals. Another concern is that financial inclusion is a fortified finance-development hybrid agenda that grant financial sector agents, financial market actors and rent-seeking capitalist greater powers to extract rents from users of certain financial services, and there are concerns that it can subordinate social development to capital market development (Mader, 2018).

Finally, there are lots of private interests in the financial inclusion business. Private firms see financial inclusion simply as a viable business to make profits while at the same time promising to offer affordable financial services to poor households to improve their welfare. Leaving aside the question of efficiency in distributing financial services, there are serious doubts about the ability of capitalist firms to deliver financial services to poor and vulnerable households in ways that improve the welfare of poor and vulnerable customers while at the same time pursuing profits from users of basic financial services. Overall, the merits of financial inclusion have been challenged and questioned. It is yet to be seen if financial inclusion will live up to its hype in the development space.

\section{Sub-optimal levels of financial inclusion}

\subsection{High supply, little or no demand}

Some reasons for little or no demand for financial services may be due to lack of awareness, lack of interest in formal financial services and excess documentation and paperwork requirements. On the other hand, excess supply of basic financial services may be caused by the presence of many financial intermediaries in a town, village or city. When there is excess supply of basic financial services with little demand, financial institutions will have one of two choices to make. They can either do nothing, or reduce the amount of financial services being offered. If they do nothing, they will supply financial services at their own expense since nobody is using the services. If they reduce the amount of financial services being offered, they can, at least, breakeven by ensuring that they have an optimal amount of financial services to meet an existing little demand for those services.

The level of financial inclusion is suboptimal when there is high supply of basic financial services with little or no demand for basic financial services. Consider a scenario where there are many financial institutions willing to offer basic financial services to anyone including poor households but there is little or no demand for basic financial services. Policy makers can exert pressure on regulated financial institutions to deliver basic financial services to poor and rural communities that do not really need those services as they prefer their own informal banking systems such as keeping money in safe boxes.

Policy makers can persuade banks to open multiple bank branches in poor and rural communities. Banks can use super agents to deliver financial services to members of poor and rural communities that reside in areas where it is too costly to open and maintain a bank branch, in order to increase supply of basic financial services. Sometimes, members of poor and rural communities feel they do not really need such basic financial services to live their normal lives but policy makers insist that people in poor and rural communities should be brought to the formal financial sector regardless of whether they want it or not. 
Basic financial services, when introduced to a poor rural community, may be new to members of the community which can lead to little or no demand for such services at its early stage.

With little or no demand for basic financial services, financial institutions can initiate an agent-induced demand (AID) program where they send in agents to poor communities to persuade them to use basic financial services. Financial institutions can send financial educators to such communities to make them aware of available basic financial services and to inform them of the benefits of using such services as a way to stimulate demand for available basic financial services. This type of demand is an agent-induced demand. The most notable downside of agent-induced demand is that while it can lead to increased demand for basic financial services, users can immediately abandon such services if they feel it does not improve their welfare due to rising cost and for other reasons.

When there is little or no demand, the government can introduce policies that make owning a bank account a requirement for receiving citizens' financial benefits, and this is form of policy-induced demand (PID). The only problem with PID is that it does not guarantee or encourage continuity in the use of basic financial services. Assuming there is adequate supply of basic financial services, and the government want to use policy tools to make people use basic financial services such as getting everyone to open a bank account. In such scenario, policy makers can use policy tools to make people open a bank account but they cannot use policy tools to compel people to continue basic financial services every time. Users of

basic financial services will often take into account convenience, cost-savings and other considerations as a criterion in determining whether to continue using certain financial services.

\subsection{High demand, little or no supply}

The level of financial inclusion is suboptimal when there is little or no supply of basic financial services to match high demand for basic financial services. Some reasons for the little or no supply of basic financial services may be caused by the non-existence of financial intermediaries in a town, village or city. On the other hand, the high demand for financial services may be due to greater awareness and interest in formal financial services by individuals and households, and the little or no documentation and paperwork requirements.

When there is little or no supply of basic financial services with high demand, there are just two rational options for policy makers. One, policy makers can bring in one or more financial institutions into the town, city or rural community. Two, they can choose to do nothing! If they do nothing, the rural communities will continue using their informal finance systems. If they bring in new financial institutions into cities, towns or rural communities, such financial institutions must be licensed and should have the capacity to meet the high demand for basic financial services while remaining profitable or at least to breakeven in the short-run.

Consider a scenario where there are communities that do not have a single financial institution or communities that have few dysfunctional financial institutions. Policy makers can persuade existing financial institutions (e.g. banks) to open a branch in excluded communities. The challenge is that the decision to open a bank branch in rural communities is a strategic business decision to be made by the management of the bank, and the proposal to open a branch in rural communities may be rejected by the 
management of a bank if the cost-benefit analysis shows that opening a bank branch in such locations is not profitable.

With little or no supply of basic financial services, policy makers can also introduce policy-induced supply programs. For instance, policy makers can require banks to set up branches in rural and excluded communities, and in exchange, the participating banks will be granted regulatory forbearance for their regulatory breaches, and also, such banks will be permitted to draw up a portion of their cash reserve ratio (with the central bank) as a reward for participating in branch expansion programs that improve financial inclusion. This is just one example of how policy-induced supply programs can increase the supply of basic financial services. While there are many types of supply-side programs that can be used to stimulate supply, it is important to understand that the ability of providers of basic financial services to continue providing such services depends on the average cost of offering such services

\section{The Conditions for Optimality in financial inclusion}

The optimal level of financial inclusion is one that (i) grants access to basic financial services, (ii) provides basic financial services at a price that is affordable to the poorest and excluded population, (iii) and such price is equally sufficient to encourage the provision of such financial services on a continued basis. These conditions are discussed in detail below:

\section{- There should be access to basic financial services}

Access to basic financial services should be granted to all individuals especially poor individuals and households. The most basic form of access to financial services is through account ownership in a bank or formal financial institution (Allen et al, 2016). Account ownership in a formal financial institution allow individuals to have access to loans and savings products to meet their subsistence, personal and emergency needs. But account ownership alone is not enough as there are structural and economic barriers that hinder access to financial services such as financial illiteracy, high transaction costs, distance from a bank, ignorance, lack of education, among others.

To ensure full access to financial services, account ownership should be supported with digital alternatives such as mobile money, mobile wallets, etc. Also, policy makers can use moral suasion to persuade the providers of financial services to remove or lower price barriers that prevent access to financial services. While access to financial services is important, it is also important to understand that granting access to financial services does not mean that everybody will use basic financial services. But what it does mean is that basic financial services are available at all times to individuals and households so that they can use those services whenever they need to. Thus, granting access to financial services is a condition for achieving optimal financial inclusion.

\section{- Basic financial services should be offered at a price}

Basic financial services should be offered at a price, not necessarily, free of charge. Making basic financial services available to the poorest and excluded population at zero cost has the advantage of encouraging poor households to use basic financial products and services for their benefit but it would also imply that 
the providers of financial services will bear the cost themselves or consider the cost as a sunk-cost of doing business. If providers of financial services bear the cost, they may provide basic financial services at zerocost for the first, say, two or three years, and may discontinue the provision of such services in later years as it may not be profitable to do so in the long term.

Also, providing basic financial services at zero cost can be welfare-decreasing to users of financial services as it can make users of financial services to take welfare-destructing financial decisions such as a customer opening five to seven bank accounts for no real economic purpose, or a customer placing requests for multiple credit cards and debit cards when they have no money in their bank accounts. Furthermore, providing basic financial services at zero cost can be incentive-inefficient to providers because it can discourage providers from providing such financial services when there is little incentive to do so. Also, in the absence of government subsidy or guarantee, there may be little or no incentive for providers to offer quality formal (and basic) financial services to poor individuals and the excluded population. But when financial services come at a cost, users of financial services will make better and efficient decisions in using basic financial services while providers of financial services will have economic incentives to provide basic financial services at a reasonable cost.

\section{- The price should be affordable to the poor and excluded population}

The cost of financial services should be affordable to users especially poor users. An affordable price is one that poor people and members of the excluded population can comfortably afford. Sometimes, an affordable price may mean a very low price. A low price is desirable to encourage poor users to use basic financial services while high cost of financial services can discourage poor people from using basic financial services, and there is evidence that high cost of financial services discourage poor people from using financial services (Chakrabarty, 2011; Bhanot et al, 2012; Ozili, 2018). One idea to lower the cost of financial services is to use differential pricing that favours poor people. This involves charging a low fee to poor users and charging the standard fee to everyone else. This approach works in practice but the downside of using this approach is that providers of financial services may be accused of engaging in discriminatory pricing practices.

\section{- The price should be economically sufficient to encourage continuous provision}

Setting a price that covers the unit cost of a financial service will encourage the provision of the financial service on a continuous basis. Such pricing ensures that the marginal benefit of using a financial service is equal to the marginal cost of delivering the financial service to the customer which is analogous to a profit maximization solution, given as: $\pi \equiv M B=M C$, where $\pi=$ profit function, $M B=$ marginal benefit and $M C=$ marginal cost. The economically sufficient price can also be an equilibrium price where the equilibrium price $\left(\mathrm{P}_{\mathrm{e}}\right)$ is the price at the intersection of the demand for basic financial services and the supply of basic financial services as shown in figure 1. 


\section{Figure 1}

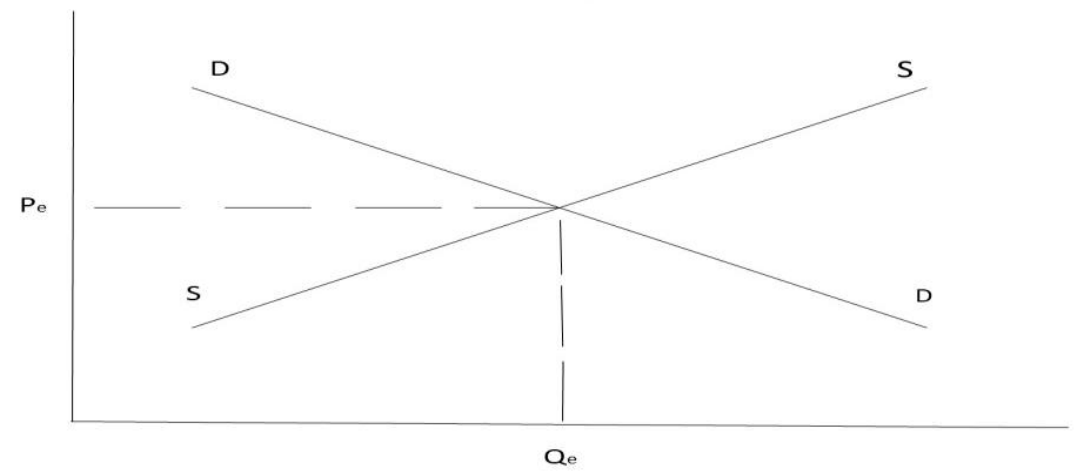

\section{Conclusion}

This paper discussed the conditions for optimality in financial inclusion. It argued that the optimal level of financial inclusion is one that (i) grants access to basic financial services, (ii) provides basic financial services at a price that is affordable to the excluded population (iii) and such price is equally sufficient to encourage the provision of such financial services on a continued basis. It argued that basic financial services should be offered to people at a price - not free of charge - to make it sustainable. The implication is that governments through the central bank may need to work together with financial institutions to provide financial services at low cost. Of course, the government can by-pass financial institutions to meet its financial inclusion goals by giving direct cash benefits to poor citizens but this step will also be suboptimal. Future research should explore the association between optimal financial inclusion and financial crises. Future studies can also investigate other forms of sub-optimal levels of financial inclusion. 


\section{Reference}

Agarwal, R. (2007). 100\% Financial Inclusion: A challenging task ahead.

Ahamed, M. M., \& Mallick, S. K. (2019). Is financial inclusion good for bank stability? International evidence. Journal of Economic Behavior \& Organization, 157, 403-427.

Allen, F., Demirguc-Kunt, A., Klapper, L., and Martinez Peria, M.S. (2016). The Foundations of Financial Inclusion: Understanding Ownership and Use of Formal Accounts. Journal of Financial Intermediation, 27, 1-30.

Anzoategui, D., Demirgüç-Kunt, A., \& Martínez Pería, M. S. (2011). Remittances and financial inclusion: evidence from El Salvador. The World Bank.

Arun, T., \& Kamath, R. (2015). Financial inclusion: Policies and practices. IIMB Management Review, 27(4), 267-287.

Ayres, R. L. (1983). Banking on the poor: the World Bank and world poverty (pp. 185-9). London: Mit Press.

Beck, T., Demirgüc-Kunt, A., Levine, R. (2007). Finance, Inequality and the Poor, Journal of Economic Growth 12, 27-49. 5.

Beck, T., Demirgüç-Kunt, A., \& Honohan, P. (2009). Access to financial services: Measurement, impact, and policies. The World Bank Research Observer, 24(1), 119-145.).

Bhanot, D., Bapat, V., \& Bera, S. (2012). Studying financial inclusion in north-east India. International Journal of Bank Marketing, 30(6), 465-484.

Bruhn, M., \& Love, I. (2014). The real impact of improved access to finance: Evidence from Mexico. The Journal of Finance, 69(3), 1347-1376.

Chakrabarty, K. C. (2011). Financial inclusion and banks: Issues and perspectives. RBI Bulletin, November.

Chibba, M. (2009). Financial inclusion, poverty reduction and the millennium development goals. The European Journal of Development Research, 21(2), 213-230.

Cnaan, R. A., Moodithaya, M. S., \& Handy, F. (2012). Financial inclusion: lessons from rural South India. Journal of Social Policy, 41(1), 183-205.

Cull, R., T. Ehrbeck, and N. Holle, 2014. "Financial Inclusion and Development: Recent Impact Evidence." CGAP (Consultative Group to Assist the Poor), Focus Note 9/2014.

Demirgüç-Kunt, A. (2014). Presidential address: Financial inclusion. Atlantic Economic Journal, 42(4), 349356.

Duvendack, M; Palmer-Jones, R.; Copestake, J.G.; Hooper, L.; Loke, Y. and Rao, N. (2011) What is the Evidence of the Impact of Microfinance on the Well-Being of Poor People?, Systematic Review, London: EPPI-Centre, University of London. 
Duvendack, M; Palmer-Jones, R.; Copestake, J.G.; Hooper, L.; Loke, Y. and Rao, N. (2011) What is the Evidence of the Impact of Microfinance on the Well-Being of Poor People?, Systematic Review, London: EPPI-Centre, University of London.

Guérin, I.; Labie, M. and Servet, J. (2015) The Crises of Microcredit. London: Zed Books

Fraser, N. (2011) 'Feminism, Capitalism, and the Cunning of History’. New Left Review 56, 97-117

Hayton, K., Percy, V., Latimer, K., \& Chapman, M. (2007). Financial inclusion: a topic report from the Scottish Household Survey. Scottish Government Social Research.

Han, R., and M. Melecky. 2013. Financial Inclusion for Financial Stability: Access to Bank Deposits and the Growth of Deposits in the Global Financial Crisis. World Bank Policy Research Working Paper No. 6577. Washington, DC: World Bank.

Hannig, A., \& Jansen, S. (2010). Financial inclusion and financial stability: Current policy issues. ADBI Working Paper No. 259.

Jones, P. A. (2008). From tackling poverty to achieving financial inclusion-The changing role of British credit unions in low income communities. The Journal of Socio-Economics, 37(6), 2141-2154.

Kim, D. W., Yu, J. S., \& Hassan, M. K. (2018). Financial inclusion and economic growth in OIC countries. Research in International Business and Finance, 43, 1-14.

Mitton, L. (2008). Financial inclusion in the UK: Review of policy and practice. Joseph Rowntree Foundation.

Mohan, R. (2006). Economic growth, financial deepening, and financial inclusion. Dynamics of Indian Banking: Views and Vistas, 92-120.

Neaime, S., \& Gaysset, I. (2018). Financial inclusion and stability in MENA: Evidence from poverty and inequality. Finance Research Letters, 24, 230-237.

Ozili, P. K. (2018). Impact of digital finance on financial inclusion and stability. Borsa Istanbul Review, 18(4), 329-340.

Ozili, P. K. (2020). Financial inclusion research around the world: a review. Forum for social economics.

Park, C. Y., \& Mercado, R. (2015). Financial inclusion, poverty, and income inequality in developing Asia. Asian Development Bank Economics Working Paper Series, (426). Asian Development Bank, Philippine.

Ranjani, K. S., \& Bapat, V. (2015). Deepening Financial Inclusion beyond account opening: Road ahead for banks. Business Perspectives and Research, 3(1), 52-65.

Sarma, M., \& Pais, J. (2011). Financial inclusion and development. Journal of international development, 23(5), 613-628. 
Sarma, M. (2012). Index of Financial Inclusion-A measure of financial sector inclusiveness. Centre for International Trade and Development, School of International Studies Working Paper Jawaharlal Nehru University. Delhi, India.

Triki, T., \& Faye, I. (2013). Financial inclusion in Africa. African Development Bank.

United Nations. (2016). Digital financial inclusion. international telecommunication union (itu), issue brief series, inter-agency task force on financing for development, July. United Nations. Available at: http://www.un.org/esa/ffd/wp-content/uploads/2016/01/Digital-Financial-Inclusion_ITU_IATFIssueBrief.pdf. (Accessed 10 November 2017). 